\title{
Do Confisco Como Modo de Perda da Propriedade Imóvel.
}

\author{
Paulo Carneiro Maia \\ Professor Adjunto de Direito Civil, da Faculdade \\ de Direito da Universidade de São Paulo.
}

\begin{abstract}
Sumário. 1. Lineamentos Gerais. - 2. Breve escorço de outra modalidade especifica de perda da propriedade imóvel. - 3. Esquematisação do confisco. 4. Legislação insulada e seu alcance na problemática. - 5. Conclusão.
\end{abstract}

1. O nosso c. c., influente aos sedimentos de épocas que deixaram a sua estratificação, disciplinou os modos aquisitivos da propriedade imóvel e móvel ${ }^{1}$. Da mesma ma-

1. A teor do disposto no seu livro II, título II, capítulo II, adquire-se a propriedade imóvel, pelo preceituado no art. 530, incisos I a IV, ou seja, pela transcrição do título de transferência no registro de imóveis, pela acessão, pelo usucapião, pelo direito hereditário. Os três primeiros são modos originários de aquisição inter-vivos e o último é meio aquisitivo regido pelo direito das sucessões.

No plano da orientação de fundo, sem abdicar de seu entendimento sistemático, ao apreciar o primeiro dos preceitos relativos à aquisição da propriedade imóvel, CLóvis BevilaquA conclui sua observação: "O Código Civil reconhece e regula diversos modos de adquirir. Uns aplicam-se, exclusivamente, aos móveis, como a ocupação; outros, exclusivamente, aos imóveis, como a transcrição dos títulos; uns são originários, como a acessão natural, outros derivados, como a tradição; uns a título universal; como a sucessão hereditária; outros a título singular" (Código civil comentado, Rio de Janeiro, Belo Horizonte, 3.a ed., 1930, Livraria Francisco Alves, vol. III, pg. 64, ob. 3).

Da aquisição e perda da propriedade móvel, preocupou-se o legislador pátrio no capítulo III, do mesmo livro e seção I (arts. 592 a 
618), na secção II trata da ocupação (individualizados como da caça, da pesca, da invenção e do tesouro), nas secções II, III e IV da especificação, da confusão, comistão, adjunção, do usucapião e da tradição.

Dos primeiros particularizados (da caça) e do terceiro (da invenção e do tesouro), ocupou-se WASHINGTON DE BARros MONTEIRo, nas suas mais recentes divulgações específicas (Do direito de caça na legislação brasileira, in Problemas Brasileiros, 1971, ano VII, n. ${ }^{\circ}$ 91, pp. 30/38. Da invenção e do tesouro, como modos de adquirir a propriedade móvel, in Revista da Faculdade de Direito da Universidade de São Paulo, 1970, ano LVX, pp. 55/65).

Ao analisar o direito 'de caça, perante a legislação nacional, esse civilista pátrio das Arcadas, dentre os mais comedidos, principia asseverando, com o que estamos acordés, que à semelhança da pesca são formas de ocupação, maneiras de adquirir a propriedade, apoderando-se tanto o caçador como o pescador das coisas de ninguém (res nullis, na denominação dos romanos) antes de capturadas. Nesta mesma linha firme e reta, passando a dar maior desenvolvimento, assentou ele, à segunàa premissa. "Individualizou-as o Código Civil Brasileiro" - referência induvidosa do escritor àqueles dois modos de ocupação, caça e pesca - para complementar o enunciado: "como figuras jurídicas, mas, nem por isso, deixaram de ser espécies desse modo aquisitivo da propriedade, tão velho quanto a própria humanidade" (cit. vol. de Problemas Brasileiros, pág. 30).

Procedido o confronto com o "Anteprojeto do Código Civil", de 1972, da comissão elaboradora e revisora, da qual foi supervisor MIGUEL. REALE, nota-se que a matéria Do Direito das Coisas, mereceu tratamento distinto e na parte especial no livro III, capítulos II e III, com - título $D a$ aquisição da propriedade imóvel e da móvel dá ênfase ao tema. No art. 1.431, que se segue à disposição geral, lê-se: "Adquirem-se pelo usucapião e pela sucessão hereditária tanto a propriedade imóvel quanto a móvel", caidando das demais maneiras de aquisição nas secções sezuintes.

Embora o anteprojeto tenha abraçado a mesma doutrina do código de 1916, inaugurou critório dispositivo de ordem inversa, situando, de início, o "usucapião" (que antes era o terceiro caso do art. 530) menos usual, ainda, em se tratando de coisa móvel, a que ora se deu preferência - e depois a sucessão hereditária ("direito hereditário", que era o caso IV do art. 530 primitivo), com indiferença às conquistas inflexíveis.

Afigura-se-nos que o critério discriminativo anterior, na ordem do que era havido de maior relevância e mais usual, mexecia preservar-se observadas as adequações cabíveis. 
neira, distintamente, contempla a perda da propriedade imóvel ${ }^{2}$, assim como da móvel ${ }^{3}$.

Com sensível suporte, mas sem atingir a recolocação da "sucessão hereditária", o que certamente passou despercebido, momentoso foi o reparo de CAIo MÁrTo DA Silva PeReIRA, à margem a aparente ironia, destituída de cunho construtivo, a que se prestava, ao ventilar o assunto com o título Aquisição da propriedade imóvel. "Começa o Anteprojeto pelo usucapião, isto ê, por aquilo que é menos freqüente. Questão de gosto. Ou indício de falta de realismo. $E$ na disciplina do usucapião, dá a sua preferência pelo de coisa móvel, que é de extrema raridade".

No usucapião de coisa imóvel, o Anteprojeto adotou um sistema da maior complexidade" (Crítica ao anteprojeto de código civil, in Revista do Instituto dos Advogados Brasileiros, ano VI, n. ${ }^{\circ} 20$, n. ${ }^{\circ} 129$, pg. 64).

2. Edita o art. 589, do c. c.: “Além das causas de extinção consideradas neste Código, também se perde a propriedade imóvel:

I. Pela alienação.

II. Pela renúncia.

III. Pelo abandono.

IV. Pelo perecimento do imóvel (vide art. 78).

$\S 10^{\circ}$ Nos dois primeiros casos deste artigo, os efeitos da perda do domínio serão subordinados à transcrição do título transmissivo, ou do ato renunciativo, no registro do lugar do imóvel.

§ 2. 0 imóvel abandonado arrecadar-se-á como bem vago, e passará, dez anos depois, ao domínio do Estado, ou ao do Distrito Federal, se se achar nas respectivas circunscrições ou ao da União, se estiver em território ainda não constituido em Estado".

$\mathrm{O}$ atual anteprojeto adotou melhor plano porque, depois de cogitar Da aquisição da propriedade imóvel e da móvel (arts. 1.431/1.438), bem como dos modos de aquisição daquela (parte especial, livro III, título I, capítulos II, III e IV, arts. 1.439/1.453) e dessa (arts. 1.454/1.465), ficou registrado com antecedência, consagrou no capítulo $\mathrm{V}$ à perda da propriedade, a teor do quanto sôa, com relacionamento:

“Art. 1.466. Além das causas consideradas neste Código, perde-se a propriedade:

I. Pela alienação.

II. Pela renúncia.

III. Pelo abandono.

IV. Pelo perecimento da coisa.

V. Pela desapropriação. 
Note-se que, aí, o tratamento é em conjunto, ou melhor, tanto o do modo aquisitivo da coisa móvel com o da sua perda. Quanto à propriedade imóvel a disposição semelhante a da posse ${ }^{4}$, foi diversa, não padecendo do mesmo defeito, pois, adotou melhor forma distributiva, capitulando distintamente a aquisição da perda da propriedade imóvel ${ }^{5}$.

Esta matéria de perda da propriedade imóvel, no direito anterior, não estava sistematizada, conquanto seja notório e até acentuado por comentadores que as causas extintivas delas eram idênticas. Não encerra ela "numerus clausus".

Parágrafo único. Nos dois primeiros casos deste artigo, os efeitos da perda da propriedade imóvel serão subordinados à transcrição do título transmissivo, ou do ato renunciativo, no Registro de Imóveis".

Bem andou o anteprojeto no plano topográfico atrás resumido. E desde que assegurou, em disposições distintas (arts. 1.466 e 1.467), subordinadas à mesma epígrafe, "Da perda da propriedade" sua sistematização é louvável a inclusão da "desapropriação", como modalidade de perda da propriedade (inciso V). Eliminou-se, assim, a incongruência primitiva (c. c., art. 590) para conglobá-lo em preceito mais próprio e panorâmico.

No mais foi mantida, praticamente, senão mutatis mutandis, a mesma linguagem, exceção da usada no caput (art. 1.466 do "projeto") que eliminou no início da frase a expressão "de extinção" e no final dela o vocábulo "imóvel", acredita-se, pela idéia de incidência em superfetação decorrente da natureza do capítulo, orientado à perda da propriedade do imóvel. Houve alteração, sim, no inciso IV do art. 589 c.c., que mencionava "perecimento do imóvel" e o "projeto" substituiu por “coisa", a acarretar outra dimensão.

3. Realmente, o mencionado capítulo III, tem a epigrafe $D a$ aquisição e perda da propriedade móvel, ao oposto da posse que foi considerada distintamente, isto é, quanto a sua aquisição no capítulo II (arts. 493 a 519) e no tocante a perda dela no capítulo IV (arts. 520 a 522).

4. Vide nota 3 anterior, especialmente, na sua segunda parte.

5. No capítulo II, com o título da propriedade imóvel, subtítulos (secção I) da aquisição da propriedade imóvel (arts. 530 a 533) e da perda da propriedade imóvel (secção VI), em três preceitos dispositivos (arts. 589 a 591), modelou-se mais a contento. 
Precisa-o aquele primeiro cânone civil, que se segue a titulação (art. 589), com a expressão empregada "além das causas de extinção consideradas neste Código" encerrando os quatro casos. E como o c.c., cuidou, ainda do usucapião (art. 530, inciso III e 550), da acessão nas suas cinco formas (art. 536) e da dissolução do casamento (art. 262), constituem essas causas de extinção de propriedade imóvel, não incluidas expressamente na mencionada secção, porém, presentes porque ocorre "em detrimento do proprietário anterior" ". No subsequente dispositivo (c. c., art. 590) está aduzido que também se perde a propriedade imóvel" mediante desapropriação por necessidade ou utilidade pública" 7

Assiste inteira razão a JoÃo LuIs Alves quando precisa que, fora parte as causas de perda da propriedade imóvel, "mencionadas nos ns. 1 a 4 deste artigo e no artigo seguinte, outras existem" ".

6. Clóvis Beviláqua, op. vol. cits., p. 131, J. M. DE CiarvalHo Santos, Código civil brasileiro interpretado, Rio de Janeiro, 2.a ed., 1937, vol. VIII, pg. 200;

7. Regula a faculdade expropriatória pelo poder público, o que deita âncora no direito constitucional (c. f. de 1969, art. 153, § 22), ressalvada a peculiaridade do usucapião pro-labore (cit. c. f., art. 161). Não está ele assim delimitado. Adverte WAshingtoN DE BARros MONTEIRo, afastado o ensejo de contradita: "Não se pense, porém, apesar do disposto no art. 550 do Código Civil, que a sua utilidade se circunscreva à aquisição da propriedade, porquanto a ele se pode eficarmente recorrer para a aquisição de outros direitos reais, como as servidões e o dominio util na enfiteuse" (Curso de direito civil, Direito das coisas, São Paulo, Edição Saraiva, 8. ${ }^{\text {a }}$ edição, 1970, pg. 126).

8. Em apanhado feliz e de alto alcance, perpetuou o civilista, o que é elogiável tanto pela estética como pelo conteúdo: “Assim, perde-se também a propriedade:

a) Quando a coisa passa a nova condição que a põe fora do nosso poder físico, como se o campo é tomado pelo mar (Dir. Cous., § 91) caso de perecimento, art. $78, n .^{\circ}$ III);

b) Quando o domínio se resolve (arts. 647 e 648, Dir. Cons. $\S 62$ ); 
2. Da pormenorização, que traduzem os lineamentos gerais antes precisados, resulta existir outra causa de perda da propriedade imóvel, além das previstas no c.c., Queremos nos referir ao confisco, "sanctio juris", senão precisá-lo, remontando à sua raiz histórica, emanado da prática do enriquecimento ilícito, que ao Presidente da República foi cometido decretar, nos moldes da legislação vigente, resultante do poder revolucionário.

Não constitui mais problema a ser colocado e devassado aquele de um direito revolucionário e o da Revolução Brasileira de 1934, que restabeleceu o direito de confisco. Atua ela "através de regulamentação jurídica por ela própria traçada, como aliás sucede com todo movimento revolucionário". Di-lo José Frederico Marques, em aprofundado e ainda atual parecer, acrescentando: "O Poder Supremo, no Estado brasileiro, que a revolução encarna, para lhe ordenar a vida jurídica, tem nos atos institucionais, o instrumento destinado a traçar as regras gerais, que se superpondo a todos os outros preceitos e normas, demarcaram as fronteiras não só das atribuições dos diversos órgãos estatais, como ainda do poder normativo do próprio órgão máximo da revolução, que é o Presidente da República".9

Antes mesmo de relembrar o étimo do vocábulo, convém salientar que, como precedente histórico, a confiscação aparece na História do Brasil, segundo prática imposta quanto os bens dos jesuitas. Em afirmativa solene e básica, lê-se no fim da quinta capa da nossa História Pátria, que pela "Carta Régia" de 25.II.1761, D. João V, fillho de D. Pedro II de Portugal," determina o confisco de todos os bens

c) Quando há arrematação em hasta pública ou adjudicação, casos de alienação judicial (art. 532, n. ${ }^{\circ}$ III);

d) Quando se verifica o usucapião, que faz com que o possuidor adquira a propriedade que outrem perde (arts. 550 e 551); etc." (JOÃO Luis Alves, Código Civil da República dos Estados Unidos do Brasil, Anotado, São Paulo, 1935, 2. ${ }^{\text {a }}$ ed., tiragem, vol. I, pg. 535).

9. Confisco de bens por enriquecimento ilicito, parecer com este título, s/d., in Revista de Direito Público, 1969, ano III, vol. 9, pg. 95), 
dos jesuitas, exceto os de serviços religiosos", que na época se encontrassem no Brasil. ${ }^{10}$

O reflexo da legislação adiante compendiada, respeitante ao confisco, a ser identificada, não afasta a dedução, antes, aproxima o passado (século XVIII) e o presente (século $\mathrm{XX)}$ para permitir a inferência de que se trata do mesmo instituto, de confiscação do patrimônio. Daí suas raízes longínquas, no domínio histórico, sendo perfeitamente harmoniosa sua contestura abrangente do patrimônio.

3. Confisco ou confiscação, vocábulo derivado do latim confiscatio, de confiscare - em sentido restrito, é o ato pelo qual são apreendidos, ou adjudicados ao fisco bens pertencentes a outrem, mediante a atuação administrativa ou decisão judicial, fundados em lei.

O confisco, em tese, qualifica uma punição. É a sanctio juris "provinda do enriquecimento ilícito", que o Presidente da República pode decretar nas hipóteses capituladas e discriminadas em legislação de exceção e tendente a assegurar o prosseguimento da revolução de março de 1964". ${ }^{11}$

Está isto a significar que a decretação ou a imposição do confisco ${ }^{12}$, como configuração atual, por óbvio, resulta da prática de enriquecimento ilícito, fruto de crime ou contravenção efetivada por quem, afora outras sanções, ficou sujeito, por imposição legal, a perda parcial ou total dos seus bens, em proveito do erário público. Pode, ainda, o adquirente de tais bens concorrer ou contribuir, de algum modo, para a realização daquele ato, caracterizando-se a co-autoria.

10. História do Brasil do Museu Histórico Nacional, pelos professores AfFonso Celso de CARvalho, LaURyston Guerra e Herculano MATHIAS, Rio de Janeiro, Bloch Editores S/A., vol. 1, fascículo 9, pg. 145.

11. José Frederico Marques, op. vol. cits. pg. 98.

12. Está patente, pela essência desse ensaio, não deixando dúvidas, ademais, seu próprio título, que se cuida do confisco, na modalidade de perda da propriedade imóvel, proveniente de lei insulada, ampliativa 
Cumpre avivar a lembrança não caber confusão entre suspensão dos direitos políticos e o confisco. Ambos assentam no mesmo ato institucional $\mathrm{n} .^{\circ}$ 5, a seguir apreciado: dimanam dos "fundamentos e propósitos" que o motivaram, segundo até expresso nos "considerandos" justificativos de sua edição, tendentes a assegurar o prosseguimento da revolução de $1 .^{\circ}$ de Março de 1964 "conforme decorre dos atos com os quais se institucionalizou", na letra do seu "considerando" preambular. $O$ primeiro, na ordem de colocação, tem amparo no art. 4, ouvido o C. S. N., seguindo-se decreto específico limitado seu prazo a 10 anos, alcançando a cassação de mandatos eletivos — ou a condenação pela justiça militar na maioria das vêzes consectário da punição criminal. $O$ segundo, tem por fundamento o art. 8 encerrando nova forma de perda de propriedade. Uma coisa é a suspensão dos direitos políticos, sem cunho duradouro ("pelo prazo de 10 anos"), outra, bem diversa, é "decretar o confisco de bens de todos quantos tenham se enriquecido, ilicitamente, no exercício de cargo ou funções públicas", sem prejuízo das sanções penais cabíveis, o que importa na perda da propriedade por confisco.

do rol dos casos previstos no c.c. Não está em jogo matéria fiscal, em torno da apreensão de mercadoria contrabandeada ou posta no comércio en contravenção das leis fiscais, a motivar a apreensão, por parte do poder público, com o direito ao confisco para cobrar-se dos tributos devidos e suas multas. Tão pouco, no permissivo penal, a apreensão autorizada pelo julgador, dos instrumentos e do produto do delito. Menos ainda do confisco cambial, que JoSÉ MARIA WHITAKER, quando de novo no Ministério da Fazenda, em 1955, "resistindo a prudente e honrada orientação aconselhada" por aquele seu ministro, "o Governo Federal recusou-se a dar início à extinção gradual do nefasto confisco cambial, que atingira as raias da alucinação na aventura bolsista e dos leilões de câmbio, decorrentes da instrução n. 70 de 1953", o que foi mais recentemente rememorado por F'RANCISCO MALTA CARDOSO em primorosa e confessada intervenção afirmativa, que constituiu a continuada insurgência de São Paulo, ao relatar: "O confisco cambial, exigindo numerário cada vez maior, para a transformação em cruzeiros, dos dólares 
4. Os atos institucionais, assim como os complementares e os decretos-leis que forem e têm sido baixados pelo governo revolucionário de 1964, interligados com os preceitos constitucionais de 1967 , estabelecem o ciclo de suas fontes normativas no contexto daqueles atos e decretos leis que estratificaram um direito adequado aos fins triunfanfes, daquilo que se apresentava precário, insuficiente ou superado.

Desta posição hierárquica ${ }^{13}$, ressaltam os primados das regras, mesmo sem este "nomen juris", que estabeleceram o confisco como modalidade de perda da propriedade imóvel.

e mais moedas fortes tomadas de seus legítimos donos, porque produtores da mercadoria que o produziam, tornou-se o fator máximo e inexorável da inflação brasileira" (Confisco. Uma causa e seus efeitos, in Problemas Brasileiros, 1971, n. ${ }^{\circ}$ 90, pg. 30).

13. Nesse lance, que tem sua oportunidade, com o título Hierarquia das Normas, ao desenvolver o que de início denominara "taxonomia de todas as normas e fontes formais do direito brasileiro", para logo fazer refletir a incidência delas no caso da consulta que motivara seu parecer, o mesmíssimo JosÉ Frederico MARQUES alongou-se na observação propícia, depois da parte introdutória, a saber: "Detentor do poder revolucionário, como seu supremo dirigente, o Presidente da República está limitado, em seus poderes e atribuições, por aquilo que se contém nos atos institucionais, uma vez que nestes a Revolução possui o instrumento necessário para estabelecer sua orientação geral e básica. Movimento ordenado e dirigido por seu próprio direito, a Revolução se expressa, no tocante aos postulados que disciplinam juridicamente a sua atuação, por intermédio dos atos institucionais.

Trata-se de autolimitação, justamente institucional, tal como a conceitua Maurice Hauriou, uma vez que esta se apresenta como a autolimitação "com que o Estado se constitui de tal maneira, que a limitação funciona dentro de si próprio, mediante certa disposição de sua organização interna" (cf. JEAN DABIN, Doctrina General del Estado, 1946, pg. 157).

A autolimitação é interna, ao invés do que sucede no regime constitucional, em que as restrições vêm de fora, pois o Estado, subordinan- 
Dentre semelhantes medidas de exceção assume relevo 0 ato institucional $n .^{\circ} 5$ de 13.XII.1968 que, afora explicitadas prerrogativas, conferiu o direito de confisco ao Chefe da Nação contra os que se enriqueceram, ilicitamente, "no

-do-se à Constituição, "toma a decisão de submeter-se a uma norma que lhe é alheia" (J. DABIN, ob. e loc. cits.).

Na Revolução Brasileira, esta se limita por suas próprias normas, o que o faz com os atos institucionais. Por isso, quando as diretrizes, em algum desses atos traçados, se revelam precárias, isuficientes e superadas, novo ato pode ser baixado para que de outro modo se opere a autolimitação. $\mathrm{E}$ isto se coaduna perfeitamente com o caráter contingente do Direito Revolucionário.

De qualquer forma, porém, é no ato institucional que reside a expressão máxima do poder normativo da revolução. O que vem estatuído em ato dessa natureza, só por outro ato institucional pode ser alterado ou modificado. E a posição hierárquica do ato institucional alcança culminância tão elevada, que a própria Constituição se coloca, perante ele, em posição subalterna. A revolução, por ser movimento atuante na vida do Estado brasileiro, possui o denominado poder constituinte, uma vez que é ordem jurídica originária. $\mathrm{E}$ o poder constituinte, como assinala RECASENS SICHES, "es por su naturaleza ilimitado, absoluto, en tanto en cuanto no se halla sometido a ningún ordenamiento positivo, $y$ en tanto en cuanto no deriva su competência, de ningún otro poder, sino que se funda sobre si mismo, en si mismo, a fuer de primeiro y originario. La actuacion del poder constituyente representa una formación originaria de Derecho; $y$ por lo tanto no está regulado por ningún orden jurídico preexistente" (Vida Humana, Sociedad y Derecho, 1952, pg. 317).

$\mathbf{E}$ esse poder constituinte a revolução o exerce, justamente, através dos atos institucionais.

Se o ato institucional promana do poder de formação originária do Direito, que é poder constituinte da Revolução, os demais atos normativos, emanados do próprio poder revolucionário, já assim não se caracterizam. Quando atos complementares ou decretos leis são baixados, o órgão que os promulga recebe esse poder dos atos institucionais, pelo que a competência para tal fim, além de "baseada no Direito constituĺdo", também se encontra "limitada e regulada por este" (cf. RECASENS Siches, ob. cit., pg. 319).

O primado do ato institucional, como regra baixada pelo poder constituinte da evolução, submete a seus ditames os atos complementares 
exercício de cargo ou função pública, inclusive de autarquias, empresas públicas e sociedades de economia mixta" 14 .

Desdobra-se a providência do confisco em dois momentos, representativos de dois atos que lhes correspondem: o primeiro deles cinge-se ao procedimento preliminar em que é ou não decretado o confisco; o segundo, que é a resultante do confisco, consiste no processo rescisório objetivando a revogação do confisco antes da decretação dele. Ficou pre-

e os decretos-leis, uma vez que a promulgação destes não é exercício do poder constituinte da revolução, e sim do poder por esta constituído através justamente dos atos institucionais.

$\mathrm{O}$ ato complementar, como o nome o está indicando, é ato destinado a dar complemento aos atos institucionais. Atualmente, segundo a linguagem usada pelo Ato Institucional $\mathrm{n}^{\circ} \mathbf{5}$, os atos complementares são atos de execução dos atos institucionais (art. 9. $0^{\circ}$ do Ato Institucional $n .^{\circ} 5$ ).

Isto significa que, de modo geral, o ato complementar está para o ato institucional, em relação análoga à do regulamento no tocante à lei.

Por outro lado, uma vez que o Ato Complementar n. ${ }^{\circ} 38$, de 13.12.1968, decretou o recesso parlamentar, o Poder Executivo ficou autorizado a legislar consoante o disposto no art. $2 .^{\circ}, \S 1 .^{\circ}$. do Ato Institucional n. ${ }^{\circ} \mathbf{5}$.

De notar, ainda, que o Ato Institucional n. ${ }^{\circ} 5$, manteve a vigência da Constituição de 1967, "in verbis": "São mantidas as Constituições de 24 de janeiro de 1967 e as constituições estaduais com as modificações constantes deste ato institucional" (Ato Institucional $\mathbf{n}^{\circ} \mathbf{5}$, art. $\left.1 .^{\circ}\right)$.

Donde inferir-se que as fontes normativas do direito revolucionário assim se colocam no plano hierárquico: 1) atos institucionais e os respectivos atos complementares; 2) Constituição de 1967 ; 3) decretos-leis.

Os atos complementares, desde que em harmonia com o ato complementado (isto é, norma de ato institucional), prevalecem sobre a Constituição, o que não acontecerá, no entanto, se contiverem preceituação "ultra vires" (op. vol. cits., pg. 95/96).

14. Estatui o art. 8 do Ato Institucional n. ${ }^{\circ} 5$, textualmente e por inteiro: "O Presidente da República poderá, apoos investigação, decre- 
visto, inicialmente, no seu art. 9; depois regulada no diploma que lhe seguiu, atinente à matéria ${ }^{15}$.

Seguiu-se o acenado dec-lei 359, de 17.XII.1958, criando a comissão geral de investigações e dando outras providências. Coerente com os anteriores ditames, prescreve o seu art. 1.": "Fica instituída, no Ministério da Justiça, a Comissão Geral de Investigações com a incumbência de promover investigações sumárias para o confisco de bens de todos quantos tenham enriquecido, ilicitamente, no exercício de cargo ou função pública, da União, dos Estados, do Distrito Federal, dos Territórios ou dos Municípios, inclusive de empregos das respectivas autarquias, empresas públicas ou sociedades de economia mista". No art. 2 desse diploma legislativo ficou preestabelecida a forma pela qual a investigação será instaurada, a denotar que os órgãos da revolução não devem, nem podem agir com arbítrio e sim "securdum legis". Fiel à segurança desse pensamento, José FredERIGo Marques adianta: "As normas e regras do direito revolucionário devem ser obedecidas ainda que dentro do relativismo jurídico que as estrutura. Esse o motivo pelo qual o enriquecimento ilícito, como outro fator do confisco de bens, deve ser configurado objetiva e subjetivamente, segundo os contornos da legislação revolucionária. Se a espécie a ser examinada não se enquadra nos tipos legais de enriquecimento ilícito, não cabe o confisco, uma vez que este é a "sanctio juris" pertinente àquele ato antijurídico" ${ }^{16}$.

tar o confisco de bens de todos quantos tenham se enriquecido ilicitamente, no exercício de cargo ou função pública, inclusive de autarquias, empresas públicas e sociedades de economia mista, sem prejuízo das sanções penais cabíveis" (in Lex, 1958, legislação federal, pp. 1.489/1.490).

15. Cfr. arts. 2 e 3 do Dec-lei $n .^{\circ} 359$, de $17 . X I I .1958$ que cria a comissão geral de investigações e dá outras providências (in Lex, 1968, Legislação federal, pg. 1.489/1.490).

16. Op. vol. cits. pg. 98. 
Foi também no aludido diploma legislativo, em seu artigo 6, que se conceituou o locuplemento indevido ${ }^{17}$, apesar de sua acepção genérica. ${ }^{18}$.

17. Está redigido assim o art. 6, do invocado Dec-lei $n .^{\circ} 359$, de 17.XII.1968: “Considera-se enriquecimento ilícito, para os efeitos deste decreto-lei, a aquisição de bens, dinheiros ou valores, por quem tenha exercido ou exerça cargo ou função pública da União, Estados, Distrito Federal, Territórios e Municípios, assim como das respectivas autarquias, empresas públicas ou sociedades de economia mista, sem que à época da aquisição, dispuzesse de idoneidade financeira para fazê-lo, à vista da declaração de rendimentos apresentada para fins de pagamento do imposto de renda.

Parágrafo único. Considera-se, também, enriquecimento ilícito, a aquisição de bens, dinheiros ou valores por quem tenha exercido ou ainda exerça cargo ou função pública da União, Estados, Distrito Federal, Territórios ou Municípios, assim como das respectivas autarquias, empresas públicas ou sociedades de economia mista, e que embora dispondo, à época da aquisição, de idoneidade financeira para fazê-lo, não haja comprovado a sua legitimidade perante a Comissão".

18. Posto aquela qualificação tivesse obedecido ao sentido restrito que lhe atribuiu o mencionado Decreto-lei $n .^{\circ} 359$ de 17.XII.1968, não será ocioso, antes comporta esquematizar, a idéia generalizada do tema.

O nosso c.c. "não considerou expressamente a doutrina do enriquecimento ilícito no sentido de tomá-lo como figura especial, ou melhor como causa geradora de obrigação". (J. M. DE CARvalho SANTos, Código civil brasileiro interpretado, vol. II, 2. ${ }^{a}$ ed., pg. 378; CoSTA MaNso, Votos e Acórdãos, ed. 1922, p. 223). Mas mesmo os que entendem, "que a modalidade do enriquecimento sem causa legítima", toma o "aspecto do pagamento indevido, subordinado ao título do próprio pagamento", como sintetiza JORGE AMERICANo (Ensaio sobre o enriquecimento sem causa, ed., 1933, n. $\left.{ }^{\circ} 7,19\right)$, não deixam de reconhecer que "ao locupletamento sem causa legítima, portanto, não se aplica uma teoria de contornos definidos, que o faça revestir aspecto distinto e facilmente reconhecível por característicos rigorosos". (op. cit. n. ${ }^{\circ} 16$, pg. 30). De modo que, uma tal ação, para uns, deixa de ter fundamento legal e, para outros, baseia-se em uma teoria sem contornos definidos. Segundo aqueles, conseguintemente deve ser julgada carecedor da ação desde que não há direito correlato (c.c., art. 75). Segundo esses deverão ser provados certos requisitos indispensáveis, que adiante serão realçados e, se não o forem, a ação deverá ser julgada improcedente. A ação de enriquecimento sem causa, na falta de batismo exato, motivou que se 
Antecede o art. 5, a dispor no seu parágrafo único, que publicado o decreto de confisco, - com a especificação dos bens abrangidos, na letra da cabeça do mandamento, que não comporta distorções - "no Diário Oficial, se se tratar

fosse "chercher en droit romain le nom de l'action de in rem verso, et c'lest ainsi qu'on appelle, dans le jurisprudence et dans la doctrine, l'action donnee pour répeter l'enrichissement sans cause" (Planiol, Traité elementaire de droit civil, 2. ${ }^{\mathrm{a}}$ ed., vol. II, n. ${ }^{\circ}$ 935, pg. 290) mas, "modernamente, deixou de ter aquela aplicação especializada, para tomar a acepção de ação de locuplemento indébito, socorrendo a todo aquele que tenha sofrido uma lesão patrimonial, e não possa invocar uma relação obrigacional oriunda das fontes ordinárias das obrigações" (JoRge AMERICANO, op. cit., n..$^{4}$, pg. 11; Costa Manso, op. cit., pg. 223). Se, pois, o locuplemento indevido tem como pressuposto as conditiones, "que são as ações onde se nota precipuamente a influência da eqüidade" (JoRGE AMERICANo, op. cit., n. ${ }^{\circ}$ 5, pg. 14), deve ser especificado em qual das condictios (indebite; sine causa; ob finitam causam; ob turpem vel injustam causam; causa data, causa non secuta) se funda para acionar. $\mathrm{E}$, isto, é indispensável desde que o fundamento da ação tem mais caráter doutrinário do que legal. Quer se acolha o princípio de que o locuplemento, sem causa assenta na eqüidade, com PoMPôNIo na vanguarda, ou na lei que veda o enriquecimento com a jactura alheia (c.c. arts. 159, 964), mesmo sem debater a teoria das causas, será mister a configuração de requisitos essenciais. Tais elementos substanciais, em número de quatro, são: $1 .^{\circ}$ ) o locuplemento, isto é, o proveito, a vantagem auferida porque sem ele não há enriquecimento de outrem; $\left.2 .^{\circ}\right)$ o empobrecimento correlativo de outra parte verificado ao mesmo tempo em que ocorrer o enriquecimento do culpado; $3 .^{\circ}$ ) a falta de justa causa e consentimento, ou seja, a ilegitimidade do proveito colhido e sem a concorrência de vontade do prejudicado, visto como as vantagens patrimoniais obtidas com justa causa são protegidas pelo direito; $\left.4 .^{\circ}\right)$ a relação de causalidade entre o enriquecimento e o empobrecimento achando-se um ato ligado ao outro pelos vínculos de causa e efeito. (J. M. DE CaRvalho SANTOS, op. vil. cits. pg. 383; Costa Manso, op. cit., pg. 226; M. I. CARvalho DE MendonçA, Doutrina e prática das obrigações, ed. 1908, n. ${ }^{\circ}$ 272, pg. 330; Planiol, op. vil. cits., n. ${ }^{\circ} 936$, pgs. 290/1). Portanto, a ação deverá ter estes requisitos, comprovados de início, sem o que não deve ser conhecida. Esta demonstração é de todo necessária e porque ao "autor incumbe a prova de que fez a prestação para solver determinada dúvida, bem como a prova de que a dívida não existia. Apesar de se tratar de prova negativa, não se transfere 
de bens imóveis, o Ministro da Justiça no prazo de trinta dias, remeterá cópia ao Secretário da Justiça, ou autoridade equivalente dos Estados, Distrito Federal ou Territórios, para que determine aos Titulares dos Registros de Imóveis a transcrição dos bens em nome da Fazenda Pública."

para o réu o ônus de produzi-la sob feição positiva, devido ao fato da culpa do autor, em pagar o que não devia, culpa da qual pode ter resultado a destruição da prova pelo réu" (JORGE AMERICANo, op. cit., n. ${ }^{\circ} 4$, pgs. 16/17). Além disto "para que o pagamento sem causa não se inclua na hipótese legitimada na lei, da simulação inocente, é indispensável a prova do erro". (JORGE AMERICANo op. eit., n. ${ }^{0} 8$, pg. 22). Acresce notar que "se a vontade do prejudicado concorreu não se pode falar em enriquecimento ilicito, porque volenti non injuria". (J. M. DE CARvalHo SANTOS, op. vol. pg. 387).

Em precioso estudo monográfico mais atual, porque divulgado em 1957 (separata do vol. 259, da Rev. Trib. pgs. 3/36 ou cit. fonte; Rev. Forense, vol. 173 pgs. 47/67) com o título Do enriquecimento sem causa, - prestigiado civilista e professor circunstancia a problemática acerca de tão sedutor e fecundo tema. Principia esquematizando a actio de in re verso, e o motivo de não ser ela "de largo uso entre nós", para examinar textos legais em que o princípio do enriquecimento ilícito está implícito. Mostra a fundamentação, que para ele é a moral, pois é aquela que "mais diretamente" está "relacionada com a condenação do enriquecimento, esteja ela expressa, ou simplesmente latente na ordenação". Ventila as objeções e o trabalho dos doutrinadores e da jurisprudência, nos países em que não há texto expresso a respeito. Entra a examinar os requisitos da ação, um a um, sendo seu opúsculo uma contribuição sintética e condensada para todo aquele que hoje pretenda versar o enriquecimento sem causa.

O anteprojeto de 1972, também na parte especial (livro I, título VII, capítulo IV), reservou este último (arts. 942 a 944) ao $D o$ enriquecimento sem causa, mostrando-se, todavia, exíguo frente à disciplinação atual da matéria. $\mathbf{E}$ por tal comportamento não isentou-se da crítica que lhe fez CAIO MárIo da Silva Pereira: "O anteprojeto conserva-se na mesma linha superada do Código Civil, a respeito do assunto. o que modernamente se estabelece é a disciplina do enriquecimento sem causa como gênero. $\mathrm{E}$, dentro dele, o pagamento indevido entra como especificação subordinada aos princípios gerais.

O anteprojeto, entretanto, dá a mesma ênfase ao pagamento indevido, destinado ao instituto geral apenas preceitos acanhados" (op. vol. cits., n. ${ }^{\circ} 115$, pg. 56). 
Tal dispositivo completa a modalidade registrada, que flui do próprio ato institucional n. ${ }^{\circ} 5$, de 13 .XII.1968 ${ }^{20}$, sem distorções. Sua inclusão, ademais, seria indispensável como parte de um todo planificado. Mesmo porque esse modo de perda da propriedade imóvel condensa um processo que se cumpre, na pureza de sua efetivação, negando ou largando ao esquecimento o propósito inicial, cuja autenticidade repousa na fidelidade de sua origem e possibilidade de execução inflexível.

Finalmente, o ato complementar n. ${ }^{\circ} 42$, de 27.I.1969, no seu art. $1 .^{\circ} 21$, imprimiu melhor dedutibilidade àquela norma anterior, de indiscutível valia.

Descabe a insinuação de José Frederico Marques de que ocorreu, á, ampliação da área de incidência ${ }^{22}$, porque ele mesmo reconhece, após esse enunciado, não ter dúvida de que a suposta - momentoso interpolar o adjetivo - ampliação "está em harmonia com os princípios informativos do art. 8 do ato institucional $n .^{\circ} 5$ ". Corrobora a certeza do argumento, a superar o que antecede, quando reconhece

19. Cit. Dec.-lei n. ${ }^{\circ} 359$, de 19.XII.1969, apud Lex 1968, legislação federal, pg. 1.490 .

20. Vide nota 14 e texto a que faz alusão.

21. Reza o predito cânone, que não legislou ultra vires, pois sua apreciação se harmoniza com os princípios informativos do A.I. n. ${ }^{\circ}$, de 13.XII.1968, antes lembrado: "O Presidente da República, após investigação, poderá decretar o confisco de bens de pessoa natural ou jurídica que, em relações de qualquer natureza, com a administração da União, dos Estados, do Distrito Federal, dos Territórios e dos Municípios, autarquias, empresas públicas, sociedades de economia mista e fundações instituídas com auxílios ou contribuições estabelecidos em lei, permissionárias ou concessionários de serviços públicos, se haja enriquecido, ilicitamente, com bens, dinheiros ou valores, sem prejuízo das sanções penais cabíveis.

Parágrafo único. Aplica-se, também, o disposto neste artigo a quem, de qualquer modo, concorrer para o enriquecimento ilícito" (in Lex, 1969, legislação federal, pgs. 75/76).

22. Op. vol. cits., pg. 97. 
ser ociosa, nesta altura do assunto, qualquer controvérsia por ter $o$ ato institucional $n .^{\circ} 6$, de 1.II.1969, ratificado as emendas constitucionais feitas por atos complementares posteriores àquele de 1968 analisado. E também por isto a débil lembrança de ressalva aos direitos de terceiros, pela atuação possessória, não entusiasma. Nem mesmo pelo prisma da nulidade porque envolve questão sob outra esfera jurídica e deslocada. Além do mais porque tal especiosa situação é alcançada pela superação da ociosidade de qualquer disputa, pelo alto grau de exeção da hipótese, de esdrúxula configuração e pela extensão do art. 8 do ato institucional n. 5, de 13.XII.1968, o qual menciona "bens", indistintamente, a abranger qualquer modalidade.

O sentido desta ratificação vem compendiado nas considerações, de largo convencimento e aguda penetração, da retro alvejada iniciativa de reafirmação de que não havia exaurido aquele "poder constituinte".

Seria mister, em tarefa cuidadosa, qual a adotada, que a legislação emanada, fosse coordenada na seqüência da institucionalização como direito estratificado para justificar e conduzir à conclusão atingida.

5. Na planificação dos fins e dos objetivos, que informam os atos jurídicos, se alcança à culminância que o título do presente esboço de estudo prevê, autorizando aquela proposição estatuída.

Ao fim, atentando-se ao quanto ficou apresentado, atinge-se a conclusão plena de que o diploma específico (cit.

23. José Frederico Marques, op. vol., cits., pgs. 97 e 99. Dispõe, realmente, o art. 3 do A.I. n. ${ }^{\circ}$ 6, de 1.II.1969: "Ficam ratificadas as emendas constitucionais feitas por Atos Complementares, subseqüentes ao Ato Institucional n. ${ }^{\circ}$, de 13 de dezembro de 1968 (in Lex, de 1969, legislação federal, pg. 87). 
ato institucional . $^{\circ} 5$, de 13. XII.1969) sobre confisco, por sua natureza, estabelecendo modalidade singular de perda da propriedade imóvel (bem confiscado), além do rol preexistente, tornou-o direito privado de complexão granítica, aumentando-lhe o número dos precedentes.

São Paulo, 7 de março de 1973. 